\title{
Rевевси Автісік: Effect of organic and inorganic nutrient management on growth and yield of soybean
}

\section{A.N. MEHETRE, G.B. SURYAWANSHI, U.S. SURVE AND V.V. PANCHAL}

Article Chronicle :

Received :

19.07.2017;

Accepted :

03.08.2017

KeY WORDS:

FYM, Vermicompost, GRDF, Biofertilizers,

Growth characters

Author for correspondence :

\section{A.N. MEHETRE}

Department of

Agronomy, Post

Graduate Institute,

Mahatma Phule Krishi

Vidyapeeth, Rahuri,

AHMEDNAGAR (M.S.)

INDIA

Email : ambadasmehetre

@ gmail.com

See end of the article for

authors' affiliations
SUMMARY : The field experiment was conducted during Kharif 2014 at the Agronomy Farm, College of Agriculture, Kolhapur on sandy clay loam soil with the combined application of chemical fertilizers, FYM and biofertilizers in soybean resulted increased growth and yield. Treatment 100 per cent GRDF gave significantly higher plant height $(30.68,55.63,64.98,73.90 \mathrm{~cm})$, trifoliate leaves $(4.06,13.13,21.82$, $30.10)$, number of branches $(1.13,3.26,6.12,6.89)$, dry matter production $(2.69,15.60,23.06,33.84 \mathrm{~g})$ and leaf area $\left(47.59,90.53,110.57,118.57 \mathrm{dm}^{2}\right)$ at $28,42,56$ DAS and at harvest, respectively and soybean seed yield $\left(29.22 \mathrm{q} \mathrm{ha}^{-1}\right)$ and straw yield $\left(36.01 \mathrm{q} \mathrm{ha}^{-1}\right)$ it was followed by treatment 75 per cent RDF+ vermicompost $2.5 \mathrm{tha}^{-1}$.

How to cite this article : Mehetre, A.N., Suryawanshi, G.B., Surve, U.S. and Panchal, A.A. (2017). Effect of organic and inorganic nutrient management on growth and yield of soybean. Agric. Update, 12(TECHSEAR-7) : 1899-1903; DOI: 10.15740/HAS/AU/12.TECHSEAR(7)2017/1899-1903. 